\title{
Life on the fringe: microbial adaptation to growth on carbon
}

\section{monoxide [version 1; peer review: 3 approved]}

\author{
Frank T. Robb (D)1, Stephen M. Techtmann (iD)2 \\ 1Department of Microbiology and Immunology, and Inst of Marine and Environmental Technology, University of Maryland, \\ Baltimore, Baltimore, MD, 21202, USA \\ ${ }^{2}$ Department of Biological Sciences, Michigan Technological University, 1400 Townsend Drive, Houghton, MI, 49931, USA
}

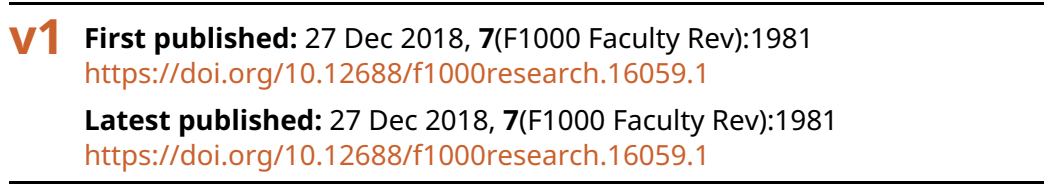

\section{Abstract}

Microbial adaptation to extreme conditions takes many forms, including specialized metabolism which may be crucial to survival in adverse conditions. Here, we analyze the diversity and environmental importance of systems allowing microbial carbon monoxide (CO) metabolism. $\mathrm{CO}$ is a toxic gas that can poison most organisms because of its tight binding to metalloproteins. Microbial CO uptake was first noted by Kluyver and Schnellen in 1947, and since then many microbes using $\mathrm{CO}$ via oxidation have emerged. Many strains use molecular oxygen as the electron acceptor for aerobic oxidation of $\mathrm{CO}$ using Mo-containing $\mathrm{CO}$ oxidoreductase enzymes named $\mathrm{CO}$ dehydrogenase. Anaerobic carboxydotrophs oxidize $\mathrm{CO}$ using CooS enzymes that contain $\mathrm{Ni} / \mathrm{Fe}$ catalytic centers and are unrelated to $\mathrm{CO}$ dehydrogenase. Though rare on Earth in free form, $\mathrm{CO}$ is an important intermediate compound in anaerobic carbon cycling, as it can be coupled to acetogenesis, methanogenesis, hydrogenogenesis, and metal reduction. Many microbial species-both bacteria and archaea-have been shown to use CO to conserve energy or fix cell carbon or both. Microbial CO formation is also very common. Carboxydotrophs thus glean energy and fix carbon from a "metabolic leftover" that is not consumed by, and is toxic to, most microorganisms. Surprisingly, many species are able to thrive under culture headspaces sometimes exceeding 1 atmosphere of $\mathrm{CO}$. It appears that carboxydotrophs are adapted to provide a metabolic "currency exchange" system in microbial communities in which $\mathrm{CO}$ arising either abiotically or biogenically is converted to $\mathrm{CO}_{2}$ and $\mathrm{H}_{2}$ that feed major metabolic pathways for energy conservation or carbon fixation. Solventogenic $\mathrm{CO}$ metabolism has been exploited to construct very large gas fermentation plants converting $\mathrm{CO}$-rich industrial flue emissions into biofuels and chemical feedstocks, creating renewable energy while mitigating global warming. The use of thermostable $\mathrm{CO}$ dehydrogenase enzymes to construct sensitive $\mathrm{CO}$ gas sensors is also in progress.
Open Peer Review

$\begin{array}{ccc}\text { Approval Status } & \\ 1 & 2 & 3\end{array}$

version 1

27 Dec 2018

Faculty Reviews are review articles written by the prestigious Members of Faculty Opinions. The articles are commissioned and peer reviewed before publication to ensure that the final, published version is comprehensive and accessible. The reviewers who approved the final version are listed with their names and affiliations.

1. Matt Schrenk, Michigan State University East Lansing, MI, USA

\section{Elizaveta Bonch-Osmolovskaya,}

Winogradsky Institute of Microbiology, Moscow, Russian Federation

3. David Grahame, Uniformed Services University of the Health Sciences, Bethesda, Maryland 20814, USA

Any comments on the article can be found at the end of the article. 
Keywords

carbon monoxide, CO dehydrogenase, extremophile

Corresponding author: Frank T. Robb (frobb@som.umaryland.edu)

Author roles: Robb FT: Conceptualization, Funding Acquisition, Writing - Original Draft Preparation, Writing - Review \& Editing;

Techtmann SM: Conceptualization, Investigation, Validation, Writing - Original Draft Preparation, Writing - Review \& Editing

Competing interests: No competing interests were disclosed.

Grant information: This work was supported by funding from the NASA Astrobiology Institute (NNX15AM18G).

The funders had no role in study design, data collection and analysis, decision to publish, or preparation of the manuscript.

Copyright: ( 2018 Robb FT and Techtmann SM. This is an open access article distributed under the terms of the Creative Commons

Attribution License, which permits unrestricted use, distribution, and reproduction in any medium, provided the original work is properly cited.

How to cite this article: Robb FT and Techtmann SM. Life on the fringe: microbial adaptation to growth on carbon monoxide [version 1; peer review: 3 approved] F1000Research 2018, 7(F1000 Faculty Rev):1981 https://doi.org/10.12688/f1000research.16059.1

First published: 27 Dec 2018, 7(F1000 Faculty Rev):1981 https://doi.org/10.12688/f1000research.16059.1 


\section{Introduction}

Public perception of the role of carbon monoxide (CO) in biology is dominated by its reputation as a silent killer because of its toxicity. Toxicity results from tight binding of $\mathrm{CO}$ to the metallocenters in heme proteins, such as hemoglobin, myoglobin, and cytochrome oxidase ${ }^{1}$. Globally, $\mathrm{CO}$ is considered an atmospheric trace gas and rarely exceeds 1 ppm except in heavily polluted city airspaces, volcanic exhalations, or industrial flue gases $^{2}$. Volcanic exhalations have significant CO content, submarine hydrothermal vent fluids have about $100 \mathrm{nM} \mathrm{CO}$, and local pockets of moderate concentrations of $\mathrm{CO}$ are produced biogenically by bacterial fermentation ${ }^{3}$ or in soil associated with rhizosphere bacteria ${ }^{4,5}$. $\mathrm{CO}$ has high potential as an electron donor $\left(\mathrm{E}-524 \text { to } 558 \mathrm{mV} \text { for the } \mathrm{CO} / \mathrm{CO}_{2} \text { couple }\right)^{6}$. Therefore, apart from its toxicity, $\mathrm{CO}$ represents a very favorable energy and carbon source for microbial growth. In this short review, we will address aspects of microbial metabolism allowing $\mathrm{CO}$ utilization through $\mathrm{CO}$ oxidoreductase enzymes. Historically, evidence for
CO utilization by "methane bacteria" was noted by Kluyver and Schnellen in $1947^{7}$ and by Schlegel ${ }^{8}$. The pathway for energy generation in phototrophic bacteria whilst growing anaerobically in the dark ${ }^{9}$ is now known to be a widespread metabolic capability in many species of bacteria and archaea as well as some fungi and algae. $\mathrm{CO}$ forms a remarkable metabolic network with many pathways (as shown in Figure 1A), including globally significant carbon cycling routes via acetogenesis and methanogenesis, which both involve anaerobic pathways in which $\mathrm{CO}$ is a key intermediate ${ }^{10}$. The Wood-Ljungdahl (WL) pathway depicted in Figure 1B is a highly adaptable set of enzymes that allow acetate formation by acetogens as well as anaplerotic feeding through the production of acetyl-CoA in many autotrophic bacteria and archaea. Recently, microbial isolates and consortia that carry out hydrogenogenic carboxydotrophy have been identified and shown to be common in many environments. These organisms link energy-conserving hydrogenases with CO dehydrogenases.

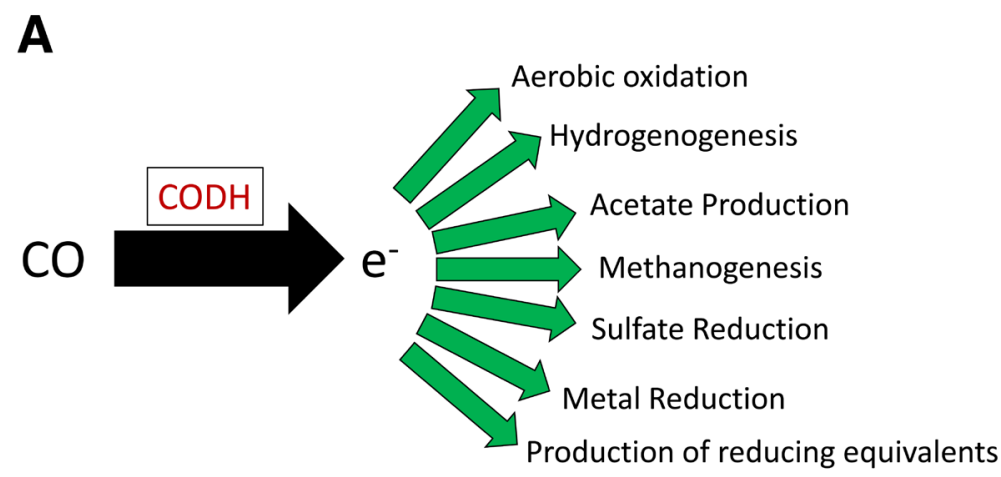

B

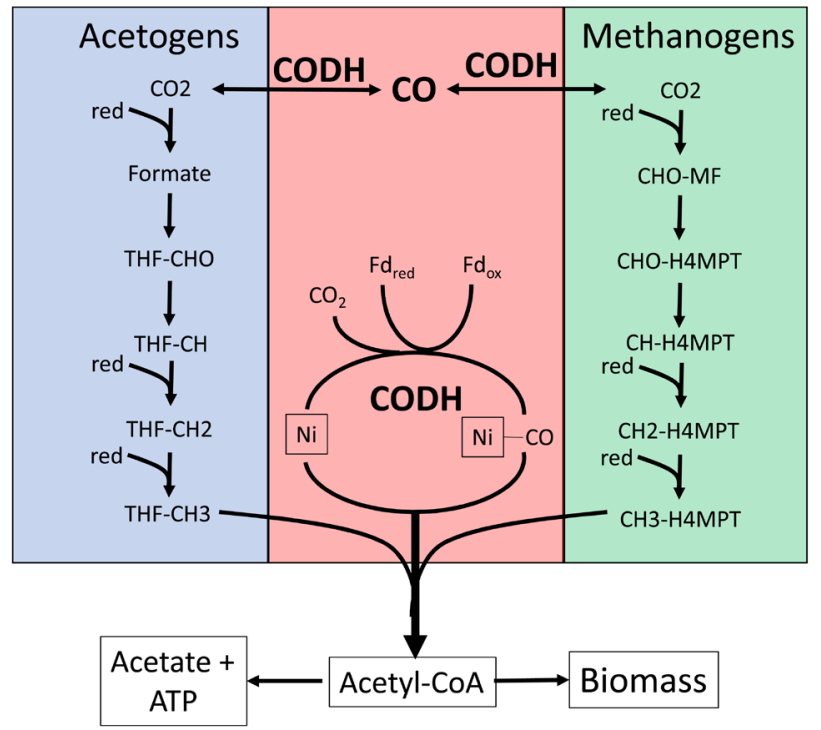

Figure 1. Carbon monoxide (CO) metabolisms and the Wood-Ljungdahl pathway. (A) Potential fates of CO in microbial physiologies. (B) Wood-Ljungdahl pathway. The carbonyl pathway is shown in pink, and the role of the CODH complex is highlighted. The generalized methyl branch of the pathway used in acetogenic bacteria is shown in blue. The generalized methyl branch of the pathway used in methanogenic archaea is shown in green. 
The organisms: $\mathrm{CO}$ as the source of energy and fixed carbon

Early studies by Kistner yielded an aerobic bacterial isolate from sewage sludge that could oxidize $\mathrm{CO}^{11}$, and this physiology is now represented by a large and diverse group of aerobic CO-oxidizing bacteria that use molecular $\mathrm{O}_{2}$ as an electron acceptor, reviewed by King and Weber ${ }^{4}$. Carboxydotrophs are a diverse and eclectic set of organisms ranging from the Proteobacteria to the Firmicutes and some archaea. Anaerobic CO oxidation in purple bacteria was described by Uffen ${ }^{9}$ in the 1970s and Kistner $^{11}$ in the 1950s, leading to steady advances in the microbiology of CO metabolism. A large variety of coupled metabolic processes and synergistic microbial metabolic interactions have now been discovered.

The substantial number of emerging bacterial and archaeal genomes containing $\mathrm{CODH}$ catalytic subunit encoding genes ${ }^{9}$ reveal that many classes of bacteria use $\mathrm{CO}$ oxidation either as a standby energy conservation strategy or as their major carbon source. Table 1 shows a selection from these strains together with their major CO-utilization pathways ${ }^{9-21}$.

$\mathrm{CO}$ can fuel a number of metabolisms, including aerobic carboxydotrophy, acetogenesis, methanogenesis, and sulfate reduction. Many carboxydotrophic strains are capable of oxidizing $\mathrm{CO}$ with water to form $\mathrm{CO}_{2}$ and $\mathrm{H}_{2}$, known as the water-gas shift reaction, as follows: $\mathrm{CO}+\mathrm{H}_{2} \mathrm{O} \Leftrightarrow \mathrm{CO}_{2}+\mathrm{H}_{2}$.

This physiology has been well studied in isolates capable of performing hydrogenogenic carboxydotrophy, found in anaerobic bacteria and $\operatorname{archae}^{22}$. A number of these thermophilic hydrogenogens are found within the genera Carboxydothermus, Thermincola, and Carboxydocella. Some other isolates such as Desulfotomaculum carboxydivorans can couple CO oxidation to sulfate reduction. Other isolates such as Carboxydocella thermautotrophica ${ }^{23}$, Thermosinus carboxydivorans ${ }^{24}$, and Carboxydothermus ferrireducens ${ }^{17}$ are able to link $\mathrm{CO}$ oxidation to metal reduction in addition to sulfate reduction. While both methanogens and acetogens employ $\mathrm{CO}$ as an intermediate in the WL pathway and use $\mathrm{CO}$ as a direct input into the pathway, a subset of these organisms can also produce $\mathrm{CO}$ directly ${ }^{25}$. Some methanogens, including Methanosarcina acetivorans, Methanosarcina barkeri, and Methanothermobacter thermautotrophicus, can grow on $\mathrm{CO}$ with methane production. $M$. acetivorans has a very versatile metabolic response, being able to grow on $\mathrm{CO}$ and produce acetate and formate as end products, rather than methane ${ }^{26}$. Acetogens such as Moorella thermoacetica can use $\mathrm{CO}$ as an input into the WL pathway for autotrophic growth and acetate production ${ }^{20,27}$. As genomic and metagenomic studies are increasingly used to inform physiology, it is likely that many more strains able to use $\mathrm{CO}$ will be identified.

\section{Key enzymes: aerobic and anaerobic $\mathrm{CO}$ dehydrogenases and acetyl-CoA synthases}

Oxidation of $\mathrm{CO}$ to $\mathrm{CO}_{2}$ is an exergonic reaction catalyzed in either anaerobic conditions (using many different electron acceptors) or aerobically (using molecular oxygen as the electron acceptor). Two fundamentally distinct classes of $\mathrm{CO}$ dehydrogenase catalyze globally significant metabolic reactions that result in $\mathrm{CO}$ transformation ${ }^{4,27}$. In anaerobes, the $\mathrm{CODH}$ active site

Table 1. Representative carboxydotrophic microbial species and their physiological features.

\begin{tabular}{|c|c|c|c|c|c|}
\hline CO-utilizing species & $\begin{array}{l}\text { Optimal } \\
\text { temperature, }{ }^{\circ} \mathrm{C}\end{array}$ & $\begin{array}{l}\text { CO as energy } \\
\text { source }\end{array}$ & $\begin{array}{l}\text { CO as carbon } \\
\text { source }\end{array}$ & Reference & CO pathways \\
\hline Rubrivivax gelatinosus & 34 & + & - & 12 & Ech \\
\hline Rhodospirillum rubrum & 30 & + & - & 28 & Ech \\
\hline Citrobacter sp Y19 & 35 & + & + & 13 & Ech \\
\hline $\begin{array}{l}\text { Carboxydothermus hydrogenoformans } \\
\text { Z2901 }\end{array}$ & 72 & + & + & 10 & Ech, WL, R \\
\hline Thermosinus carboxydivorans & 60 & + & + & 17 & Ech, WL \\
\hline Carboxydocella thermautotrophica & 58 & + & + & 16 & Ech, WL \\
\hline $\begin{array}{l}\text { Caldanaerobacter subterraneus subsp. } \\
\text { pacificus }\end{array}$ & 70 & + & $?$ & 15 & Ech, WL \\
\hline Thermococcus AM4 & 82 & + & - & 18 & Ech \\
\hline Thermococcus onnurineus NA1 & 85 & + & - & 19 & Ech \\
\hline $\begin{array}{l}\text { Methanobacterium } \\
\text { thermoautotrophicum }\end{array}$ & 55 & + & + & 19 & $W^{a}$ \\
\hline Oligotropha carboxidovorans OM5 & 30 & + & - & 29 & Ox \\
\hline $\begin{array}{l}\text { Thermogemmatispora carboxidivorans } \\
\text { PM5 }\end{array}$ & 55 & + & - & 21 & Ox \\
\hline Thermomicrobium roseum & 55 & + & - & 22 & Ox \\
\hline
\end{tabular}

CO, carbon monoxide; Ech, energy-conserving hydrogenase; Ox, oxygen as electron acceptor; R, redox reactive; WL, Wood-Ljungdahl. aThis methanogen strain can grow on $\mathrm{CO}$, producing methane. 
contains sulfur-coordinated $\mathrm{Ni}$ in a cubane $[\mathrm{Ni}-4 \mathrm{Fe}-5 \mathrm{~S}]$ center called the $\mathrm{C}$-cluster ${ }^{30,31}$, whereas aerobes have heterotrimeric enzymes named $\mathrm{CO}$ dehydrogenase that belong to the xanthine oxidase family with an active site containing a binuclear cluster of $\mathrm{Mo}$ and $\mathrm{Cu}(\mathrm{MoCu}-\mathrm{CODH})^{28,29}$. The $\mathrm{CO}$ dehydrogenase enzyme is a dimer of two heterotrimers, each composed of the coxL subunit (molybdenum protein), a flavoprotein, and an ironsulfur protein (FeSP). The CO dehydrogenase enzyme complex is monofunctional, resulting in rapid unidirectional conversion of $\mathrm{CO}$ to $\mathrm{CO}_{2}$. In contrast, the anaerobic enzymes have a $\mathrm{Ni}$ catalytic site and are known as CODH. They are encoded by the $\operatorname{CooS}$ gene and catalyze the reversible conversion of $\mathrm{CO}$ and $\mathrm{H}_{2} \mathrm{O}$ to $\mathrm{CO}_{2}$. A FeSP serves as both electron acceptor and donor in the reaction- $\mathrm{CO}+\mathrm{H}_{2} \mathrm{O}+\mathrm{FeSP} \rightleftharpoons \mathrm{CO}_{2}+\mathrm{FeSP}^{2-}+2 \mathrm{H}^{+}$- where both the forward and the backward reactions are very important, as they are central to anaerobic metabolic pathways of great biological significance. The CODH enzyme is found in many anaerobic and facultative microorganisms, both bacteria and archaea, but is absent in aerobic microorganisms. The coordination of nickel in the active site of all nickel-containing $\mathrm{CO}$ dehydrogenases appears to be very similar to that first revealed by Dobbek et al. ${ }^{31}$. Some anaerobic CODHs are monofunctional, producing $\mathrm{CO}_{2}$; others are bifunctional and form complexes with tightly bound accessory subunits, producing products including acetyl-CoA and $\mathrm{H}_{2}{ }^{31}$.

Table 2 lists the multiple CO-linked pathways that have been described; in these pathways, $\mathrm{CO}$ oxidation results in many alternative end products, including hydrogen, acetate, formate, reduced metal species, ethanol, and butanol.
The free energy of reaction for these exergonic couples is shown. The large $\Delta \mathrm{G}^{0}$ (151 kJ mole $\mathrm{CO}$ ) resulting from methanogenesis from $\mathrm{CO}_{2}$ and $\mathrm{H}_{2}$ is notable. The bifunctional $\mathrm{CODH}$ responsible for this reaction has been characterized as part of the carbonyl branch of the WL pathway ${ }^{32}$ (Figure 1). Another key enzyme in WL pathways is the acetyl-CoA synthase (ACS), which catalyzes the reaction of $\mathrm{CO}$ and $\mathrm{CH}_{3}$ to produce acetyl- $\mathrm{CoA}^{32}$. $\mathrm{CO}$ can be generated in situ from $\mathrm{CO}_{2}$ via the $\mathrm{CODH}$ and channeled to the ACS complex through direct interaction of the $\mathrm{CODH}$ and ACS via a gas tunnel inside the complex or directly input into the ACS in systems where CO is present ${ }^{33}$. The ACS complex is reversible, and in acetoclastic methanogens, the process can run in reverse to split the acetyl-CoA into CoA, methylated tetrahydrosarcinapterin (CH3-M4MPT), and $\mathrm{CO}^{33,34}$. The WL pathway is a major contributor to carbon cycling in anaerobic environments and contributes to global carbon fixation along with the Calvin cycle and the reductive tricarboxylic acid cycle pathway. The WL pathway is the most ancient of the three ${ }^{35}$, although the other two pathways are more prevalent on modern Earth.

Phylogenetic analysis of the catalytic subunits of the monofunctional and bifunctional enzymes has indicated that the enzyme phylogeny does not follow taxonomic distinctions ${ }^{35}$. There are a number of cases where non-related organisms have very similar catalytic subunits. Thorough analysis of genomes of carboxydotrophs has established that the monofunctional CODH can be horizontally transferred, leading to a widely distributed gene cluster in both the bacteria and the $\operatorname{archaea}^{12}$. A study performed in 2012 found that $6 \%$ of bacterial and archaeal genomes

Table 2. Coupled reactions resulting from the activities of CODH enzymes, with the molar free energy of reaction.

\begin{tabular}{|l|l|l|}
\hline Product & $\begin{array}{l}\text { Reaction } \\
\text { Reactions from CO }\end{array}$ & $\begin{array}{l}\Delta \mathbf{G}^{\mathbf{0}}, \\
\mathbf{k J ~ m o l ~ c O} \mathbf{C O}^{-1}\end{array}$ \\
\hline Formate & $\mathrm{CO}+\mathrm{H}_{2} \mathrm{O}$ à $\mathrm{HCOO}^{-}+\mathrm{H}^{+}$ & -16 \\
\hline Hydrogen & $\mathrm{CO}+\mathrm{H}_{2} \mathrm{O}$ à $\mathrm{H}_{2}+\mathrm{CO}_{2}$ & -20 \\
\hline Ethanol & $6 \mathrm{CO}+3 \mathrm{H}_{2} \mathrm{O}$ à $\mathrm{CH}_{3} \mathrm{CH}_{2} \mathrm{OH}+4 \mathrm{CO}_{2}$ & -37 \\
\hline n-Butanol & $12 \mathrm{CO}+5 \mathrm{H}_{2} \mathrm{O}$ à $\mathrm{CH}_{3}\left(\mathrm{CH}_{2}\right)_{3} \mathrm{OH}+8 \mathrm{CO}_{2}$ & -40 \\
\hline Acetate & $4 \mathrm{CO}+2 \mathrm{H}_{2} \mathrm{O}$ à $\mathrm{CH}_{3} \mathrm{COO}^{-}+\mathrm{H}^{+}+2 \mathrm{CO}_{2}$ & -44 \\
\hline Butyrate & $10 \mathrm{CO}+4 \mathrm{H}_{2}$ à $\mathrm{CH}_{3}\left(\mathrm{CH}_{2}\right) 2 \mathrm{COO}^{-}+\mathrm{H}^{+}+6 \mathrm{CO}_{2}$ & -44 \\
\hline Methane & $4 \mathrm{CO}+2 \mathrm{H}_{2} \mathrm{O}$ à $\mathrm{CH}_{4}+3 \mathrm{CO}_{2}$ & -53 \\
\hline Methanol & $\mathrm{CO}+2 \mathrm{H}_{2}$ à $\mathrm{CH}_{3} \mathrm{OH}_{2}$ & -39 \\
\hline Acetate & $2 \mathrm{CO}+2 \mathrm{H}_{2}$ à $\mathrm{CH}_{3} \mathrm{COO}^{-}+\mathrm{H}^{+}$ & -67 \\
\hline Ethanol & $2 \mathrm{CO}+4 \mathrm{H}_{2}$ à $\mathrm{CH}_{3} \mathrm{CH}_{2} \mathrm{OH}+\mathrm{H}_{2} \mathrm{O}$ & -72 \\
\hline Butyrate & $4 \mathrm{CO}+6 \mathrm{H}_{2}$ à $\mathrm{CH}_{3}\left(\mathrm{CH}_{2}\right)_{2} \mathrm{COO}^{-}+\mathrm{H}^{+}+2 \mathrm{H}_{2} \mathrm{O}$ & -80 \\
\hline n-Butanol & $4 \mathrm{CO}+8 \mathrm{H}_{2}$ à $\mathrm{CH}_{3}\left(\mathrm{CH}_{2}\right)_{3} \mathrm{OH}_{+}+3 \mathrm{H}_{2} \mathrm{O}$ & -81 \\
\hline Methane & $\mathrm{CO}+3 \mathrm{H}_{2}$ à $\mathrm{CH}_{4}+\mathrm{H}_{2} \mathrm{O}$ & -151 \\
\hline
\end{tabular}

${ }^{\mathrm{a}} \Delta \mathrm{G}^{0}$ values at standard temperature and pressure. 
contain genes for either a monofunctional or a bifunctional anaerobic $\mathrm{CODH}$ gene cluster, suggesting that these genes are widely distributed throughout the tree of life through horizontal gene transfer ${ }^{12}$. In a more recent study focused exclusively on the bifunctional $\mathrm{CODH}$, this cluster was found in 143 bacterial genomes and 106 archaeal genomes ${ }^{12}$. This suggests that the $\mathrm{CODH}$ gene cluster has been disseminated by lateral gene transfer across broad taxonomic divides. These gene clusters have been found in many of the recently described candidate phyla identified through metagenomic assembled genomes (MAGs) and representing archaea that resist cultivation ${ }^{35}$. The "virtual" archaeal phyla, Thorarchaeaota and Lokiarchaeota, which are of particular interest as they have been proposed as close relatives of the eukaryotic ancestor, both contain CODH/ACS clusters ${ }^{36}$.

The presence of the CODH gene cluster in both bacteria and archaea has been used to suggest an ancient origin of CODH. Recently, the WL pathway was proposed as the ancestral carbon fixation pathway in the last universal common ancestor (LUCA $)^{37}$. However, it is important to note that the WL pathway can operate both catabolically and anabolically and current data do not allow us to conclude that the CODH/ACS in LUCA was of the anabolic variety. CODH has been coupled to a variety of other metabolic processes in addition to the CODH/ACS complexes. The CODHs in hydrogenogenic carboxydotrophs have the ability to interact with a membrane-bound energy-conserving hydrogenase that is capable of generating hydrogen and extracellular protons ${ }^{35}$. Other coupled systems have linked CO oxidation to the production of reducing equivalents by driving the reduction of NAD (P) to NAD (P)H, coping with oxidative stress ${ }^{38}$, and providing electrons for metal reduction ${ }^{14}$. Many of these biochemical linkages are also reflected in the genetic proximity of $\operatorname{coos}$ to the functional genes in clusters that enable coregulation of the coupled functions and thus guides to the annotation of the coordinated metabolic pathways. However, there are many cases in which the $\operatorname{coos}$ gene has been found in the genome unaccompanied by annotated functional genes for $\mathrm{CO}$ metabolism $^{14,17}$. The function of many lone $\operatorname{coos}$ genes remains unknown ${ }^{12}$.

Genomes often encode more than one $\mathrm{CODH}^{12}$. The multiplicity of CODHs within the genome in many species hints at the diversity of metabolic processes that could be linked to $\mathrm{CO}$. $\mathrm{CODH}$ homologs must couple to their functional partners through exclusive protein-protein interactions, thus requiring different catalytic subunits for each functional pathway in the cell. The binding surfaces must evolve to assemble into enzyme complexes in orderly folding pathways. The CODH-ACS complexes have evolved remarkable structures with precision joining of tunnels for conduction of reactant molecules between the active sites $^{12}$, thus maintaining the rapid turnover of substrates and cofactors. The versatile carboxydotroph Carboxydothermus hydrogenoformans encodes five $\mathrm{CODH}$ gene clusters ${ }^{39}$, and although this record number of $\mathrm{CODH}$ gene clusters was thought to be an anomaly, recent genomic work has indicated several other organisms that encode equal numbers of paralogs of $\mathrm{CODH}$ genes. $C$. hydrogenoformans has the ability to regulate the distribution of $\mathrm{CO}$ into different pathways by gene regulation through two different CO-binding CooA proteins that bind $\mathrm{CO}$ and induce $\mathrm{CO}$ gene clusters differentially at different $\mathrm{CO}$ concentrations ${ }^{14}$.

Another aspect of $\mathrm{CODH}$ function is the maturation of the enzyme, which involves the correct insertion of $\mathrm{Ni}$ and $\mathrm{Fe}$ into the active site ${ }^{40}$. Although it is clear that CODH depends on the accessory protein CooC (a $30 \mathrm{kDa}$ ATPase) for maturation, the mechanisms and accessory proteins/chaperones involved in the maturation of C-cluster are emerging from recent studies ${ }^{41}$. These studies suggest that the maturation of the active site cubane $\mathrm{Ni}$ cluster may differ from one enzyme to another. In most cases, the maturation of $\mathrm{CODH}$ in recombinant production systems is dependent on the specific maturase activity of $\operatorname{coo} C$ gene product and the proteins must be co-expressed in order to produce $\mathrm{CODH}$ into which $\mathrm{Ni}$ is fully delivered ${ }^{42}$. Mutations in the $\mathrm{CooC}$ protein that cripple ATPase activity cause a deficiency in CO-dependent growth that is reversed only when high concentrations of $\mathrm{Ni}$ are added to the culture medium to compensate for the deficient maturation pathway ${ }^{43}$.

\section{The environment: distribution of CO-related genes in the environment}

Carboxydotrophs can be found in most thermal environments ${ }^{44}$ and in some non-thermal terrestrial habitats ${ }^{45}$. Whereas the initial characterization of $\mathrm{CO}$ utilization was in mesophilic organisms, subsequent isolations, particularly from thermal environments, have uncovered diverse carboxydotrophic microbes. The concentrations of $\mathrm{CO}$ in volcanic exhalations range from 50 to $110 \mathrm{ppm}$ in Italy ${ }^{4}$; however, it is likely that biogenic $\mathrm{CO}$ in dense microbial consortia (that is, hot spring or hydrothermal vent mats) is much higher, as sulfate-reducing bacteria can accumulate up to $600 \mathrm{ppm}$ in culture during late stationary phase ${ }^{46}$. Significantly, CO in the Earth's atmosphere, though between 50 and $160 \mathrm{ppb}$, is increasing regionally in the areas with large-scale anthropogenic inputs ${ }^{3}$.

In addition to these cultured members, molecular analysis of thermal environments has indicated that carboxydotrophic metabolisms and CO-related genes are commonplace in these thermal settings. One recent study used stable isotope probing to inventory the anaerobic carboxydotrophs in geothermal springs $^{2}$. The authors found that relatives of Thermincola, Desulfotomaculum, Thermolithobacter, and Carboxydocella were commonly co-labeled using ${ }^{13} \mathrm{C}$ isotopically labeled $\mathrm{CO}$. This finding suggests that the ability to use $\mathrm{CO}$ is common in hot springs and many of the relatives of isolated carboxydotrophs are active players in these geothermal settings. Another recent study demonstrated that, in some hot springs, CO was actively consumed under anaerobic conditions during incubation, suggesting an active carboxydotroph community ${ }^{47}$. Additionally, the abundance of a specific $\operatorname{coos}$ gene was quantified by using quantitative polymerase chain reaction. This work demonstrated that this $\operatorname{cooS}$ gene was present in some hot springs at greater than $10^{4}$ copies per gram of sediment. Although the copies of bacterial and archaeal 16S rRNA genes were often two orders of magnitude more abundant than the $\operatorname{coos}$ gene, in some hot springs the $\operatorname{coos}$ gene abundance was the same as the 16S rRNA 
gene abundance. These findings combine to suggest that in volcanic thermal settings $\mathrm{CO}$ is actively consumed by an abundant group of anaerobic carboxydotrophs.

Although the presence of CO-based metabolism is widely accepted in hot spring and deep-sea volcanic vent settings, the abundance of carboxydotrophs and CO-related genes in non-thermal locations is under-appreciated. Recent work has indicated that $\mathrm{CO}$-associated genes are common in deep-sea sediments ${ }^{48}$. This could be due in part to the presence of CO-related genes in members of these uncultivated phyla present in the deep ocean $^{49}$. Another recent study detected the presence of CooS genes throughout surface sediment in the oceans as well as in subsurface sediments down to $390 \mathrm{~m}^{36}$.

Rock-hosted subsurface ecosystems are also heavily influenced by microbes that encode CO-related genes. Environments influenced by serpentinization, the aqueous alteration of ironrich mantle rocks, commonly generate hyperalkaline conditions with copious reduced gas, including $\mathrm{CO}$. Metagenomic analysis of serpentinite-hosted ecosystems has indicated the presence of CO-related genes ${ }^{49,50}$. Because these systems are limited in dissolved inorganic carbon, it is suggested that these organisms are able to use $\mathrm{CO}$ as both an electron donor and a carbon source $^{51}$.

However, the presence of carboxydotrophs and CO-related genes is not limited to conventional extreme environments. Oddly, genes involved in the CODH/ACS pathway in serpentinite systems have close homologs in metagenomes of the microbiome of the termite hindgut ${ }^{51}$. Like serpentinite habitats, the termite hindgut is an extremely alkaline milieu. Many of the recovered $\operatorname{CooS}$ genes were implicated in homoacetogenic metabolism ${ }^{52}$.

These findings combine to suggest that microbial CO metabolism is more widespread than previously thought. However, many of the locales in which carboxydotrophs have been found have sparingly low concentrations of $\mathrm{CO}$. In some settings where $\mathrm{CO}$ is produced through abiotic processes, the role of carboxydotrophic microbes may be to provide a strategy for detoxification. Carboxydotrophs can remove $\mathrm{CO}$, which is toxic to many consortium members at high concentrations, and produce $\mathrm{CO}_{2}$ and $\mathrm{H}_{2}$, gases which cross-feed to other pathways such as methanogenesis and sulfate reduction ${ }^{53}$. Therefore, an alternative model is one in which carboxydotrophs act in a form of currency exchange between organisms that can produce $\mathrm{CO}$ and $\mathrm{CO}$-utilizing organisms. There is strong evidence that sulfate reducers and methanogens can produce $\mathrm{CO}$ as an end product of their metabolism, similar to fermentation end products in heterotrophic microbes. For example, as mentioned previously, the sulfate reducer Desulfovibrio vulgaris produces high levels of $\mathrm{CO}$ and certain mutants produce up to $600 \mathrm{ppm}$ of $\mathrm{CO}$ during stationary phase ${ }^{3}$. Some methanogens produce $\mathrm{CO}$ during growth $^{3}$. In mat or biofilm communities, locally high levels of $\mathrm{CO}$ may accumulate while the bulk $\mathrm{CO}$ levels remain low. Our conceptual models would suggest that biogenic $\mathrm{CO}$ can be used by carboxydotrophic microbes to fuel their metabolism and produce compounds such as $\mathrm{H}_{2}, \mathrm{CO}_{2}$, or acetate which are able to fuel other metabolisms such as methanogenesis and sulfate reduction. This form of inter-species currency exchange via $\mathrm{CO}$ or detoxification of $\mathrm{CO}$ suggests a central role for carboxydotrophs in many anaerobic ecosystems.

\section{Biotechnology and industrial applications}

Adapting carboxydotrophs to create novel and interesting large-scale processes has been increasing rapidly. Discoveries that $\mathrm{CO}$ can be not only used to generate $\mathrm{H}_{2}$ but also converted directly into a variety of liquid fuel components and chemical feedstocks, including ethanol, N-butanol, and acetone, have sparked a new field of research. There are several pilot-scale projects under way using large fermenters sparged with industrial flue gases, responding to incentives related to reduced carbon emissions. Some are coupled to hydrogen production; however, the acetogenic gas fermentation can be adapted to produce solvents from syngas or refinery flue gases in many geographic regions without competing for food or land. The production of ethanol or butanol ${ }^{26}$ and other chemical feedstocks by pilot installations using carboxydotrophs is now quite well established ${ }^{54}$. The application of metabolic engineering to adapt the mesophilic acetogen Clostridium autoethanogenum ${ }^{55}$ to large-scale gas fermentation using a range of industrial effluent gas streams is becoming sophisticated and production is now coming on stream ${ }^{56}$.

Another aspect is the development of gas sensors based on immobilized thermostable enzymes ${ }^{55}$. Biosensors with $\mathrm{CO}$ inert electrodes combined with immobilized $\mathrm{CO}$ oxidoreductase from the thermophile Pseudomonas thermocarboxovorans using phenazine ethosulfate as the electron acceptor (with $\mathrm{a} \mathrm{K}_{\mathrm{m}}$ of $3.8 \mu \mathrm{M}$ ) have shown potential for $\mathrm{CO}$ detection within the ppm to $\mathrm{ppb}$ range with durability and rapid response $\mathrm{s}^{57}$.

\section{Conclusions and future directions}

CO-based metabolism is surprisingly common in extremophilic and non-extremophilic organisms and is widely distributed throughout the tree of life. Furthermore, there is good evidence that the WL pathway is the most ancient carbon fixation route, making CO-based metabolism an ancestral physiology ${ }^{58}$. Diversification of the pathway during evolution allowed $\mathrm{CO}$ oxidation to be coupled to various metabolic processes ranging from energy conservation to carbon acquisition, metal reduction/ detoxification, and coping with oxidative stress. As burgeoning metagenomic data have revolutionized our understanding of microbial ecology, CO-related genes have been commonly found in MAGs throughout the world. This widely distributed metabolism also has great potential for recently invented industrial applications aimed at alleviating carbon emissions and mitigating climate change.

There is still much to be clarified regarding the mechanism of CO-based metabolisms. Although both monofunctional and bifunctional CODHs have been found scattered throughout the tree of life, the mechanisms of metabolic coupling to CODHs are still partially explored and the electron transfer coupling routes are in many cases not clear. Genomic synteny often underscores potential linkages; however, more biochemical characterization of monofunctional CODHs is required in order to better predict the function of $\mathrm{CODH}$ from genomic data, especially for 
CODHs that are found in MAGs or single amplified genomes (SAGs) from uncultivated microbes. However, biotechnology innovation is now being vigorously applied to use $\mathrm{CO}$ as a feedstock in novel large-scale bioengineering applications in major carbon-emitting countries, potentially lowering the carbon footprint of some heavy industries like steel production and potentially curbing the relentless trend of global warming.

\section{Grant information}

This work was supported by funding from the NASA Astrobiology Institute (NNX15AM18G).

The funders had no role in study design, data collection and analysis, decision to publish, or preparation of the manuscript.
1. Wu L, Wang R: Carbon monoxide: endogenous production, physiological functions, and pharmacological applications. Pharmacol Rev. 2005; 57(4): 585-630.

PubMed Abstract | Publisher Full Text

2. Khali MAK, Rasmussen RA: Carbon monoxide in the Earth's atmosphere: indications of a global increase. Nature. 1988; 332: 242-5. Publisher Full Text

3. Voordouw G: Carbon monoxide cycling by Desulfovibrio vulgaris Hildenborough. J Bacteriol. 2002; 184(21): 5903-11. PubMed Abstract | Publisher Full Text | Free Full Text

4. King GM, Weber CF: Distribution, diversity and ecology of aerobic CO-oxidizing bacteria. Nat Rev Microbiol. 2007; 5(2): 107-18. PubMed Abstract | Publisher Full Text

5. King GM, Hungria M: Soil-Atmosphere $\mathrm{CO}$ exchanges and microbial biogeochemistry of $\mathrm{CO}$ transformations in a Brazilian agricultural ecosystem. Appl Environ Microbiol. 2002; 68(9): 4480-5. PubMed Abstract | Publisher Full Text | Free Full Text

6. Grahame DA, DeMoll E: Substrate and accessory protein requirements and thermodynamics of Acetyl-CoA Synthesis and cleavage in Methanosarcina barkeri. Biochemistry. 1995; 34(14): 4617-24. PubMed Abstract | Publisher Full Text

7. Kluyver AJ, Schnellen CG: On the fermentation of carbon monoxide by pure cultures of methane bacteria. Arch Biochem. 1947; 14(1-2): 57-70. PubMed Abstract

8. Schlegel HR: Production, modification and consumption of atmospheric trace gases by microorganisms. Tellus. 1974; 26(1-): 11-20. Publisher Full Text

9. Uffen RL: Anaerobic growth of a Rhodopseudomonas species in the dark with carbon monoxide as sole carbon and energy substrate. Proc Natl Acad Sci U S A. 1976; 73(9): 3298-302.

PubMed Abstract | Publisher Full Text | Free Full Text

10. Techtmann SM, Colman AS, Robb FT: 'That which does not kill us only makes us stronger': the role of carbon monoxide in thermophilic microbial consortia. Environ Microbiol. 2009; 11(5): 1027-37. PubMed Abstract | Publisher Full Text

11. Kistner A: Conditions determining the oxidation of carbon monoxide and of hydrogen by Hydrogenomonas carboxydovorans. Proc Kon Ned Ak v Wet. 1954 57: 186-95.

12. Techtmann SM, Lebedinsky AV, Colman AS, et al.: Evidence for horizontal gene transfer of anaerobic carbon monoxide dehydrogenases. Front Microbiol. 2012 3: 132 .

PubMed Abstract | Publisher Full Text | Free Full Text

13. Jung G: Hydrogen production by a new chemoheterotrophic bacterium Citrobacter sp. Y19. Int J Hydrogen Energ. 2002; 27(6): 601-10. Publisher Full Text

14. Wu M, Ren Q, Durkin AS, et al.: Life in Hot Carbon Monoxide: The Complete Genome Sequence of Carboxydothermus hydrogenoformans Z-2901. PLOS Genet. 2005; 1(5): e65. PubMed Abstract | Publisher Full Text | Free Full Text

15. Sant'Anna FH, Lebedinsky AV, Sokolova TG, et al:: Analysis of three genomes within the thermophilic bacterial species Caldanaerobacter subterraneus with a focus on carbon monoxide dehydrogenase evolution and hydrolase diversity. BMC Genomics. 2015; 16: 757. PubMed Abstract | Publisher Full Text | Free Full Text

16. Sokolova TG, Kostrikina NA, Chernyh NA, et al.: Carboxydocella thermautotrophica gen. nov., sp. nov., a novel anaerobic, CO-utilizing thermophile from a Kamchatkan hot spring. Int J Syst Evol Microbiol. 2002; 52(Pt 6): 1961-7.

PubMed Abstract | Publisher Full Text

17. Sokolova TG, González JM, Kostrikina NA, et al:: Thermosinus carboxydivorans gen. nov., sp. nov., a new anaerobic, thermophilic, carbon-monoxide-oxidizing, hydrogenogenic bacterium from a hot pool of Yellowstone National Park. Int $J$
Syst Evol Microbiol. 2004; 54(Pt 6): 2353-9.

PubMed Abstract | Publisher Full Text

18. Oger P, Sokolova TG, Kozhevnikova DA, et al.: Complete genome sequence of the hyperthermophilic archaeon Thermococcus sp. Strain AM4, capable of organotrophic growth and growth at the expense of hydrogenogenic or sulfidogenic oxidation of Carbon Monoxide. J Bacteriol. 2011; 193(24): 7019-20. PubMed Abstract | Publisher Full Text | Free Full Text

19. Bae SS, Kim YJ, Yang SH, et al.: Thermococcus onurinneus sp. nov., a hyperthermophilic archaeon isolated from a deep-sea hydrothermal vent area at the PACMA-NUS field. J Microbiol Biotechnol. 2006; 16(11): 1826-31. Reference Source

20. Rother M, Metcalf WW: Anaerobic growth of Methanosarcina acetivorans C2A on carbon monoxide: An unusual way of life for a methanogenic archaeon. Proc Natl Acad Sci U S A. 2004; 101(48): 16929-34. PubMed Abstract | Publisher Full Text | Free Full Text

21. Meyer O, Schlegel HG: Biology of Aerobic Carbon Monoxide-Oxidizing Bacteria. Annu Rev Microbiol. 1983; 37: 277-310. PubMed Abstract | Publisher Full Text

22. Wu D, Raymond J, Wu M, et al.: Complete genome sequence of the aerobic COoxidizing thermophile Thermomicrobium roseum. PLoS One. 2009; 4(1): e4207. PubMed Abstract | Publisher Full Text | Free Full Text

23. F Toshchakov SV, Lebedinsky AV, Sokolova TG, et al.: Genomic insights into energy metabolism of Carboxydocella thermautotrophica coupling hydrogenogenic $\mathrm{CO}$ oxidation with the reduction of $\mathrm{Fe}(\mathrm{III})$ minerals. Front Microbiol. 2018; 9: 1759.

PubMed Abstract | Publisher Full Text | Free Full Text | F1000 Recommendation

24. Tiquia-Arashiro SM: Thermophilic Carboxydotrophs and their Applications in Biotechnology. Cham: Springer International Publishing; 2014. Publisher Full Text

25. Sokolova TG, Henstra AM, Sipma J, et al:: Diversity and ecophysiological features of thermophilic carboxydotrophic anaerobes. FEMS Microbiol Ecol. 2009; 68(2): 131-41.

PubMed Abstract | Publisher Full Text

26. Conrad R, Thauer RK: Carbon monoxide production by Methanobacterium thermoautotrophicum. FEMS Microbiol Lett. 1983; 20: 229-32. Publisher Full Text

27. Pierce E, Xie G, Barabote RD, et al.: The complete genome sequence of Moorella thermoacetica (f. Clostridium thermoaceticum). Environ Microbiol. 2008; 10(10): 2550-73.

PubMed Abstract | Publisher Full Text | Free Full Text

28. F Drennan CL, Heo J, Sintchak MD, et al:: Life on carbon monoxide: X-ray structure of Rhodospirillum rubrum $\mathrm{Ni}-\mathrm{Fe}-\mathrm{S}$ carbon monoxide dehydrogenase. Proc Natl Acad Sci U S A. 2001; 98(21): 11973-8.

PubMed Abstract | Publisher Full Text | Free Full Text | F1000 Recommendation

29. Hille R, Dingwall S, Wilcoxen J: The aerobic Co dehydrogenase from Oligotropha carboxidovorans. J Biol Inorg Chem. 2015; 20(2): 243-51. PubMed Abstract | Publisher Full Text

30. Ragsdale SW: Life with carbon monoxide. Crit Rev Biochem Mol Biol. 2004; 39(3): 165-95.

PubMed Abstract | Publisher Full Text

31. $\mathrm{F}$ Dobbek $\mathrm{H}$, Svetlitchnyi V, Gremer L, et al.: Crystal structure of a carbon monoxide dehydrogenase reveals a [Ni-4Fe-5S] cluster. Science. 2001; 293(5533): 1281-5.

PubMed Abstract | Publisher Full Text | F1000 Recommendation

32. Ragsdale SW: Enzymology of the wood-Ljungdahl pathway of acetogenesis. Ann N Y Acad Sci. 2008; 1125(1): 129-36. PubMed Abstract | Publisher Full Text | Free Full Text

33. Kocsis E, Kessel M, DeMoll E, et al:: Structure of the Ni/Fe-S protein subcomponent of the acetyl-CoA decarbonylase/synthase complex from Methanosarcina thermophila at 26-A resolution. J Struct Biol. 1999; 128(2): 165-74. PubMed Abstract | Publisher Full Text 
34. Grahame DA: Catalysis of acetyl-CoA cleavage and tetrahydrosarcinapterin methylation by a carbon monoxide dehydrogenase-corrinoid enzyme complex. J Biol Chem. 1991; 266(33): 22227-33.

PubMed Abstract

35. F Adam PS, Borrel G, Gribaldo S: Evolutionary history of carbon monoxide dehydrogenase/acetyl-CoA synthase, one of the oldest enzymatic complexes. Proc Natl Acad Sci U S A. 2018; 115(6): E1166-E1173.

PubMed Abstract | Publisher Full Text | Free Full Text | F1000 Recommendation

36. Baker BJ, Saw JH, Lind AE, et al:: Genomic inference of the metabolism of cosmopolitan subsurface Archaea, Hadesarchaea. Nat Microbiol. 2016; 1: 16002. PubMed Abstract | Publisher Full Text

37. F Zaremba-Niedzwiedzka K, Caceres EF, Saw JH, et al.: Asgard archaea illuminate the origin of eukaryotic cellular complexity. Nature. 2017; 541(7637): $353-8$.

PubMed Abstract | Publisher Full Text | F1000 Recommendation

38. Soboh B, Linder D, Hedderich R: Purification and catalytic properties of a CO-oxidizing: $\mathrm{H}_{\text {-evolving enzyme complex from Carboxydothermus }}$ hydrogenoformans. Eur J Biochem. 2002; 269(22): 5712-21. PubMed Abstract | Publisher Full Text

39. Doukov TI, Blasiak LC, Seravalli J, et al.: Xenon in and at the end of the tunnel of bifunctional carbon monoxide dehydrogenase/acetyl-CoA synthase. Biochem. 2008; 47(11): 3474-83.

PubMed Abstract | Publisher Full Text | Free Full Text

40. Techtmann SM, Colman AS, Murphy MB, et al.: Regulation of multiple carbon monoxide consumption pathways in anaerobic bacteria. Front Microbiol. 2011; 2: 147.

PubMed Abstract | Publisher Full Text | Free Full Text

41. Kerby RL, Ludden PW, Roberts GP: In vivo nickel insertion into the carbon monoxide dehydrogenase of Rhodospirillum rubrum: molecular and physiological characterization of cooCTJ. J Bacteriol. 1997; 179(7): 2259-66. PubMed Abstract | Publisher Full Text | Free Full Text

42. F Alfano M, Pérard J, Miras R, et al.: Biophysical and structural characterization of the putative nickel chaperone CooT from Carboxydothermus hydrogenoformans. J Biol Inorg Chem. 2018; 23(5): 809-817. PubMed Abstract | Publisher Full Text | F1000 Recommendation

43. F Merrouch M, Benvenuti M, Lorenzi M, et al:: Maturation of the [Ni-4Fe-4S] active site of carbon monoxide dehydrogenases. J Biol Inorg Chem. 2018; 23(4): 613-20.

PubMed Abstract | Publisher Full Text | Free Full Text | F1000 Recommendation

44. Jeon WB, Cheng J, Ludden PW: Purification and characterization of membraneassociated $\mathrm{CooC}$ protein and its functional role in the insertion of nickel into carbon monoxide dehydrogenase from Rhodospirillum rubrum. J Biol Chem. 2001; 276(42): 38602-9

PubMed Abstract | Publisher Full Text

45. King GM: Contributions of atmospheric $\mathrm{CO}$ and hydrogen uptake to microbial dynamics on recent Hawaiian volcanic deposits. Appl Environ Microbiol. 2003; 69(7): 4067-75.

PubMed Abstract | Publisher Full Text | Free Full Text
46. Chiodini G, Marini L: Hydrothermal gas equilibria: The $\mathrm{H}_{2} \mathrm{O}-\mathrm{H}_{2}-\mathrm{CO}_{2}-\mathrm{CO}-\mathrm{CH}_{4}$ system. Geochimica et Cosmochimica Acta. 1998; 62: 2673-87. Publisher Full Text

47. F Brady AL, Sharp CE, Grasby SE, et al:: Anaerobic carboxydotrophic bacteria in geothermal springs identified using stable isotope probing. Front Microbiol. 2015; 6: 897.

PubMed Abstract | Publisher Full Text | Free Full Text | F1000 Recommendation

48. F Yoneda Y, Kano SI, Yoshida T, et al.: Detection of anaerobic carbon monoxide-oxidizing thermophiles in hydrothermal environments. FEMS Microbiol Ecol. 2015; 91(9): fiv093.

PubMed Abstract | Publisher Full Text | F1000 Recommendation

49. Hoshino T, Inagaki F: Distribution of anaerobic carbon monoxide dehydrogenase genes in deep subseafloor sediments. Lett App/ Microbiol. 2017; 64(5): 355-63.

PubMed Abstract | Publisher Full Text

50. Brazelton WJ, Nelson B, Schrenk MO: Metagenomic evidence for $h(2)$ oxidation and $h(2)$ production by serpentinite-hosted subsurface microbial communities. Front Microbiol. 2012; 2: 268.

PubMed Abstract | Publisher Full Text | Free Full Text

51. F Twing KI, Brazelton WJ, Kubo MD, et al.: Serpentinization-Influenced Groundwater Harbors Extremely Low Diversity Microbial Communities Adapted to High pH. Front Microbiol. 2017; 8: 308.

PubMed Abstract | Publisher Full Text | Free Full Text | F1000 Recommendation

52. $\mathrm{F}$ Warnecke $\mathrm{F}$, Luginbühl $\mathrm{P}$, Ivanova $\mathrm{N}$, et al.: Metagenomic and functional analysis of hindgut microbiota of a wood-feeding higher termite. Nature. 2007; 450(7169): 560-5.

PubMed Abstract | Publisher Full Text | F1000 Recommendation

53. F Matson EG, Gora KG, Leadbetter JR: Anaerobic carbon monoxide dehydrogenase diversity in the homoacetogenic hindgut microbial communities of lower termites and the wood roach. PLOS One. 2011; 6(4): e19316.

PubMed Abstract | Publisher Full Text | Free Full Text | F1000 Recommendation

54. Kopke M, Liew F: Production of butanol from carbon monoxide by a recombinant microorganism. Patent, Germany. 2012

Reference Source

55. De Tissera S, Köpke M, Simpson SD, et al:: Syngas Biorefinery and Syngas Utilization. Adv Biochem Eng Biotechnol. Berlin: Springer, 2019; 166: 247-280. PubMed Abstract | Publisher Full Text

56. F Liew F, Martin ME, Tappel RC, et al: Gas Fermentation-A Flexible Platform for Commercial Scale Production of Low-Carbon-Fuels and Chemicals from Waste and Renewable Feedstocks. Front Microbiol. 2016; 7: 694. PubMed Abstract | Publisher Full Text | Free Full Text | F1000 Recommendation

57. Turner AP: Biosensors. Curr Opin Biotechnol. 1994; 5(1): 49-53. PubMed Abstract | Publisher Full Text

58. Turner AP, Ramsay G, Higgins IJ: Applications of electron transfer between biological systems and electrodes. Biochm Soc Trans. 1983; 11(4): 445-8. PubMed Abstract | Publisher Full Text 


\section{Open Peer Review}

\section{Current Peer Review Status:}

\section{Editorial Note on the Review Process}

Faculty Reviews are review articles written by the prestigious Members of Faculty Opinions. The articles are commissioned and peer reviewed before publication to ensure that the final, published version is comprehensive and accessible. The reviewers who approved the final version are listed with their names and affiliations.

\section{The reviewers who approved this article are:}

\section{Version 1}

\section{David Grahame}

Department of Biochemistry and Molecular Biology, Uniformed Services University of the Health Sciences, Bethesda, Maryland 20814, USA

Competing Interests: No competing interests were disclosed.

\section{Elizaveta Bonch-Osmolovskaya}

Research Center of Biotechnology of the Russian Academy of Sciences, Winogradsky Institute of Microbiology, Moscow, Russian Federation

Competing Interests: No competing interests were disclosed.

\section{Matt Schrenk}

Department of Earth and Environmental Sciences, Michigan State University East Lansing, MI, USA

Competing Interests: No competing interests were disclosed.

The benefits of publishing with F1000Research:

- Your article is published within days, with no editorial bias

- You can publish traditional articles, null/negative results, case reports, data notes and more

- The peer review process is transparent and collaborative

- Your article is indexed in PubMed after passing peer review

- Dedicated customer support at every stage

For pre-submission enquiries, contact research@f1000.com 